\title{
Cranberry proanthocyanidins inhibit the adherence properties of Candida albicans and cytokine secretion by oral epithelial cells
}

\author{
Mark Feldman¹, Shinichi Tanabe ${ }^{1}$, Amy Howell ${ }^{2}$ and Daniel Grenier ${ }^{1 *}$
}

\begin{abstract}
Background: Oral candidiasis is a common fungal disease mainly caused by Candida albicans. The aim of this study was to investigate the effects of A-type cranberry proanthocyanidins (AC-PACs) on pathogenic properties of C. albicans as well as on the inflammatory response of oral epithelial cells induced by this oral pathogen.

Methods: Microplate dilution assays were performed to determine the effect of AC-PACs on C. albicans growth as well as biofilm formation stained with crystal violet. Adhesion of FITC-labeled C. albicans to oral epithelial cells and to acrylic resin disks was monitored by fluorometry. The effects of AC-PACs on C. albicans-induced cytokine secretion, nuclear factor-kappa B (NF- $\kappa$ B) p65 activation and kinase phosphorylation in oral epithelial cells were determined by immunological assays.

Results: Although AC-PACs did not affect growth of C. albicans, it prevented biofilm formation and reduced adherence of $C$. albicans to oral epithelial cells and saliva-coated acrylic resin discs. In addition, AC-PACs significantly decreased the secretion of IL-8 and IL-6 by oral epithelial cells stimulated with C. albicans. This antiinflammatory effect was associated with reduced activation of NF- $\kappa \mathrm{B}$ p65 and phosphorylation of specific signal intracellular kinases.

Conclusion: AC-PACs by affecting the adherence properties of $C$. albicans and attenuating the inflammatory response induced by this pathogen represent potential novel therapeutic agents for the prevention/treatment of oral candidiasis.
\end{abstract}

\section{Background}

Candida albicans is a commensal microorganism that colonizes the oral cavity of a large proportion of humans. Although in most cases this yeast does not cause any harmful effects, an overgrowth of C. albicans may result in candidiasis. Several factors that induce changes in the oral environment can predispose individuals to oral candidiasis and include: antibiotics and corticosteroid use, xerostomia, diabetes mellitus, nutritional deficiencies, and immunosuppressive diseases and therapy [1]. More specifically, denture stomatitis is a common form of candidiasis affecting denture wearers and characterized by an inflammation of the oral mucosal areas induced by C. albicans [2]. Several virulence properties of $C$. albicans, which contribute

\footnotetext{
* Correspondence: Daniel.Grenier@greb.ulaval.ca

'Groupe de Recherche en Écologie Buccale, Faculté de Médecine Dentaire,

Université Laval, Quebec City, Quebec, Canada

Full list of author information is available at the end of the article
}

to the development of oral candidiasis have been identified. They include i) adhesins that allow these organisms to adhere to oral epithelial cells with subsequent invasion [3], ii) the capacity to form biofilm on both oral mucosa and denture devices $[4,5]$, and iii) the ability to switch from yeast form to mycelium form [6].

In mucosal infections such as oral candidiasis, the innate immunity is very important and involves neutrophils, macrophages, natural killer cells, dendritic cells, and nonhematopoietic cells, such as mucosal epithelial cells. There are two main outcomes from the interaction of innate immune cells with C. albicans: i) a direct anti-fungal activity, and ii) a regulatory activity that promotes the chemotaxis, proliferation, and terminal differentiation of cells from both innate and adaptive immune systems, through the synthesis of cytokines. Although pro-inflammatory cytokines might serve to limit the progression of infection, they may also be involved in immunopathology and tissue

\section{() Biomed Central}


destruction by inducing the secretion of host matrix metalloproteinases (MMPs) [7-10] or by provoking an uncontrollable leukocyte mobilization [11].

Despite the availability of a wide range of antifungal agents for the treatment of oral candidiasis, failure of therapy is observed frequently [12]. As a matter of fact, the ability of $C$. albicans to form biofilms on epithelial surfaces and prosthetic devices reduces its susceptibility to antifungal agents $[13,14]$. Cranberry extracts and purified compounds have been suggested as potential therapeutic agents in various areas of health, including cancer, cardiovascular diseases and infectious diseases [15-17]. More specifically, the proanthocyanidins isolated from cranberry fruits possessed unusual structures with A-type linkages containing a second ether linkage between an A-ring of the lower unit and the $\mathrm{C}-2$ ring of the upper unit $(\mathrm{O} 7 \mathrm{C} 2)$, a characteristic that has been associated with their antiadherence property [18]. In this study we investigated the ability of A-type cranberry proanthocyanidins (AC-PACs) to inhibit growth, adherence properties and biofilm formation of $C$. albicans, as well as to reduce the inflammatory response of oral epithelial cells induced by $C$. albicans.

\section{Methods}

\section{Isolation of A-type cranberry proanthocyanidins}

Cranberry proanthocyanidins were isolated from cranberry fruit (Vaccinium macrocarpon Ait.) using solid-phase chromatography as described previously [19]. Briefly, cranberry fruit was homogenized with $70 \%$ aqueous acetone and filtered, and the pulp was discarded. The collected extract was concentrated under reduced pressure to remove acetone. The cranberry extract was suspended in water, applied to a preconditioned $\mathrm{C}_{18}$ solid-phase chromatography column, and washed with water to remove sugars, followed by acidified aqueous methanol to remove acids. The fats and waxes retained on the $\mathrm{C}_{18}$ sorbent were discarded. The polyphenolic fraction containing anthocyanins, flavonol glycosides, and proanthocyanidins (confirmed using reverse-phase high-pressure liquid chromatography [HPLC] with diode array detection) was eluted with $100 \%$ methanol and dried under reduced pressure. This fraction was suspended in $50 \%$ ethanol (EtOH) and applied to a preconditioned Sephadex LH-20 column which was washed with $50 \% \mathrm{EtOH}$ to remove low-molecular-weight anthocyanins and flavonol glycosides. Proanthocyanidins adsorbed to the LH-20 were eluted from the column with $70 \%$ aqueous acetone and monitored using diode array detection at $280 \mathrm{~nm}$. The absence of absorption at $360 \mathrm{~nm}$ and $450 \mathrm{~nm}$ confirmed that anthocyanins and flavonol glycosides were removed. Acetone was removed under reduced pressure and the resulting purified proanthocyanidin extract freeze-dried. The presence of A-type bonds and the concentration of proanthocyanidins in the preparation were evaluated using various analytical methods including
${ }^{13} \mathrm{C}$ nuclear magnetic resonance (NMR), electrospray mass spectrometry, matrix-assisted laser desorption ionizationtime-of-flight mass spectrometry, and acid-catalyzed degradation with phloroglucinol $[18,20]$.

\section{C. albicans and culture conditions}

C. albicans ATCC 28366 (oral origin) was cultivated in yeast nitrogen base (YNB) broth (BBL Microbiology Systems, Cockeysville, $\mathrm{MD}$ ) $+0.5 \%$ glucose $\mathrm{pH} 7.0$ under aerobic conditions at $37^{\circ} \mathrm{C}$ for $24 \mathrm{~h}$. Cells were collected by centrifugation, washed twice with sterile physiologic saline $(0.85 \% \mathrm{NaCl})$, concentrated ten times in saline and kept at $4^{\circ} \mathrm{C}$ until further use (for less than 6 days). Cells were diluted in $\mathrm{YNB}+0.5 \%$ glucose $\mathrm{pH} 7.0$ to the appropriate concentration just before to perform experiments.

\section{Effect on C. albicans growth}

Serial 1:2 dilutions of AC-PACs in YNB broth $+0.5 \%$ glucose (from 100 to $6.25 \mu \mathrm{g} / \mathrm{ml}$ ) were prepared in a flatbottomed 96-well microplate (Sarstedt, Newton, NC). Control wells with no AC-PACs were also prepared. Then, an equal volume $(100 \mu \mathrm{l})$ of the yeast suspension $\left(5 \times 10^{4}\right.$ cells $/ \mathrm{ml}$ as determined with a Petroff-Hausser counting chamber) was added. After a 24-h incubation at $37^{\circ} \mathrm{C}$ under aerobic conditions, growth was monitored by recording the optical density at $660 \mathrm{~nm}$. Assays were performed in triplicate and repeated three times.

\section{Effect on C. albicans biofilm formation}

Two hundred and fifty $\mu \mathrm{l}$ of the yeast suspension $\left(10^{7}\right.$ cells $/ \mathrm{ml}$ ) were added to wells of a 24-well tissue culture plate (Sarstedt) containing $250 \mu \mathrm{l}$ of 1:2 serial dilutions (from 100 to $6.25 \mu \mathrm{g} / \mathrm{ml}$ ) of AC-PACs in YNB broth + $0.5 \%$ glucose $\mathrm{pH}$ 7.0. Control wells with no AC-PACs were also inoculated. After incubation for $48 \mathrm{~h}$ at $37^{\circ} \mathrm{C}$ under aerobic conditions, spent media and free-floating microorganisms were removed by aspiration and the wells were washed twice with $10 \mathrm{mM}$ phosphate-buffered saline (PBS, pH 7.4), prior to quantify biofilm by crystal violet staining, as previously reported [21]. Briefly, $0.02 \%$ crystal violet was added into wells for $45 \mathrm{~min}$, which were then washed twice with PBS to remove unbound dye. After adding $250 \mu \mathrm{l}$ of $95 \%$ ethanol into each well, the plate was shaken for $10 \mathrm{~min}$ to release the dye and the biofilm was quantified by measuring the absorbance at $550 \mathrm{~nm}\left(\mathrm{~A}_{550}\right)$. Biofilm images of unstained preparations were acquired in phase-contrast mode using an Olympus FSX100 fluorescence microscope (Olympus, Tokyo, Japan). Assays were done in triplicate and three independent experiments were performed.

\section{Effect on C. albicans biofilm detachment}

C. albicans biofilms were formed during $48 \mathrm{~h}$ as described above. After removing spent media and free-floating 
microorganisms and washing wells with PBS, biofilms were incubated with $\mathrm{AC}$-PACs at concentrations ranging from 100 to $6.25 \mu \mathrm{g} / \mathrm{ml}$ (in YNB broth $+0.5 \%$ glucose) for $30 \mathrm{~min}$ and $120 \mathrm{~min}$ at $37^{\circ} \mathrm{C}$. Control biofilms were incubated with YNB broth $+0.5 \%$ glucose alone. After incubation, biofilms were washed with PBS and quantified by crystal violet staining as described above. Assays were done in triplicate and three independent experiments were performed.

\section{Effect on adherence of C. albicans to oral epithelial cells} Human oral epithelial cells GMSM-K [22], kindly provided by Dr. Valerie Murrah (University of North Carolina, Chapel Hill, NC, USA), were cultured in Dulbecco's modified Eagle's medium (DMEM) supplemented with 10\% heatinactivated fetal bovine serum (FBS) and $100 \mu \mathrm{g} / \mathrm{ml}$ of penicillin G-streptomycin, and incubated at $37^{\circ} \mathrm{C}$ in an atmosphere of $5 \% \mathrm{CO}_{2}$. Epithelial cells were seeded at a concentration of $4 \times 10^{5}$ cells $/ \mathrm{ml}$ in above conditions in sterile 96-well clear bottom black microplates (Greiner Bio One, Frickenhausen, Germany) and incubated until confluence. Then, the wells were washed with DMEM-1\% heat-inactivated FBS, blocked with $1 \%$ bovine serum albumin (BSA) to prevent non specific fungal attachment, and treated with AC-PACs diluted in DMEM-1\% heat-inactivated FBS medium at concentrations ranging from 100 to $6.25 \mu \mathrm{g} / \mathrm{ml}$ for $1 \mathrm{~h}$ in a $5 \% \mathrm{CO}_{2}$ atmosphere at $37^{\circ} \mathrm{C}$. Control wells not treated with AC-PACs were also prepared. In parallel, cells from an overnight culture of C. albicans were suspended at $10^{9}$ cells $/ \mathrm{ml}$ in carbonate buffer $(0.15$ $\mathrm{M} \mathrm{NaCl} / 0.1 \mathrm{M} \mathrm{Na}_{2} \mathrm{CO}_{3}, \mathrm{pH} 9.0$ ), and incubated for $1 \mathrm{~h}$ with continuous shaking with $0.1 \mathrm{mg} / \mathrm{ml}$ fluorescein isothiocyanate isomer I (FITC; Sigma-Aldrich Canada, Oakville, Ontario, Canada). C. albicans were then washed three times with PBS containing 0.05\% Tween 20 and resuspended in PBS. FITC-labeled $C$. albicans were applied at a multiplicity of infection (MOI) of 15 (15 C. albicans per epithelial cell) to AC-PACs pre-treated or control epithelial cells and incubated for $30 \mathrm{~min}$ at $37^{\circ} \mathrm{C}$. All incubation and washing steps were carried out in the dark. Following incubation, unbound C. albicans were aspirated and wells were washed three times with PBS. Adhered C. albicans were determined by monitoring the fluorescence using a Synergy 2 Multi-Mode Microplate Reader (BioTek Instruments, Winooski, VT, USA). The excitation and emission wavelengths were set at 488 and $522 \mathrm{~nm}$, respectively. Image processing was performed using an Olympus FSX100 fluorescence microscope (Olympus). Images of adhered FITC-labeled C. albicans were observed at excitation and emission wavelengths of 488 and $522 \mathrm{~nm}$, respectively, as well as in phase-contrast mode. The assays were performed in triplicate and repeated three times.
Effect on adherence of $C$. albicans to acrylic resin disks Acrylic resin disks (6 $\mathrm{mm}$-diameter and $0.3 \mathrm{~mm}$-thickness) were prepared as previously described [23], washed for two $h$ in saline, and then autoclaved in saline. Non-stimulated saliva collected from five healthy volunteers was pooled, filtrated and inactivated at $60^{\circ} \mathrm{C}$ for $30 \mathrm{~min}$. Acrylic resin disks were treated in the clarified heat-inactivated saliva for $1 \mathrm{~h}$ at $37^{\circ} \mathrm{C}$ with constant shaking and rinsed twice with PBS. Disks were incubated for $1 \mathrm{~h}$ at $37^{\circ} \mathrm{C}$ with intermittent shaking in the presence of equal volumes $(100 \mu \mathrm{l})$ of FITC-labeled C. albicans $\left(10^{7}\right.$ cells/ $\mathrm{ml}$ ) and AC-PACs at concentrations ranging from 100 to $6.25 \mu \mathrm{g} / \mathrm{ml}$. Positive control consisted in disks incubated with FITC-labeled C. albicans in PBS but without ACPACs. Unlabeled C. albicans incubated with discs served as negative control. Following incubation, unbound C. albicans were aspirated and disks were washed three times with PBS. Fluorescence was measured using a Synergy 2 Multi-Mode Microplate Reader. The excitation and emission wavelengths were set at 488 and $522 \mathrm{~nm}$, respectively. Assays were performed in triplicate and repeated three times.

\section{Effect on cell surface hydrophobicity of C. albicans}

This assay was performed according to the method described by Ishida et al. [24] and using xylene as organic solvent. Briefly, C. albicans at a concentration of $10^{7}$ cells/ $\mathrm{ml}$ was incubated for $30 \mathrm{~min}$ at $37^{\circ} \mathrm{C}$ with AC-PACs at $100 \mu \mathrm{g} / \mathrm{ml}$. Yeast cells were then washed with PBS, suspended in the same buffer, and the optical density was determined spectrophotometrically at a wavelength of 660 $\mathrm{nm}$. The cells were mixed with xylene $(2.5: 1, \mathrm{v} / \mathrm{v})$, shaken for $2 \mathrm{~min}$, and the tube was left for $20 \mathrm{~min}$ at room temperature in order to obtain separation of the phases. The turbidity of the aqueous phase was read at $660 \mathrm{~nm}$. The hydrophobicity index $(\mathrm{HI})$ was calculated as $\mathrm{HI}=\left(\mathrm{OD}_{\text {con- }}\right.$ trol $\left.-\mathrm{OD}_{\text {test }}\right) \times 100 / \mathrm{OD}_{\text {control }}$, where $\mathrm{OD}_{\text {control }}=$ optical density $(660 \mathrm{~nm})$ before xylene treatment and $\mathrm{OD}_{\text {test }}=$ optical density $(660 \mathrm{~nm})$ after xylene treatment. Assays were performed in triplicate and repeated three times.

\section{Effect on the inflammatory response of oral epithelial cells stimulated with $C$. albicans}

Human oral epithelial cells GMSM-K were seeded in a 12 -well plate $\left(4 \times 10^{5}\right.$ cells/well in $\left.1 \mathrm{ml}\right)$ and cultured overnight in DMEM-10\% heat-inactivated FBS medium containing antibiotics at $37^{\circ} \mathrm{C}$ in a $5 \% \mathrm{CO}_{2}$ atmosphere to allow cell adhesion prior to the stimulation with C. albicans. The epithelial cells were pre-treated with increasing concentrations of AC-PACs $(0,25,50$, and $100 \mu \mathrm{g} / \mathrm{ml}$ ) at $37^{\circ} \mathrm{C}$ in $5 \% \mathrm{CO}_{2}$ for $1 \mathrm{~h}$ prior to stimulation with C. albicans at MOIs of 3 and 15. After a 6-h incubation with $\mathrm{C}$. albicans at $37^{\circ} \mathrm{C}$ in $5 \% \mathrm{CO}_{2}$, cell-free 
supernatants were collected and stored at $-20^{\circ} \mathrm{C}$ until used. Commercial enzyme-linked immunosorbent assay (ELISA) kits (R \& D Systems, Minneapolis, MN) were used to quantify interleukin-6 (IL-6) and interleukin-8 (IL-8) concentrations in the cell-free supernatants according to the manufacturer's protocols. The absorbance at $450 \mathrm{~nm}$ was read using a microplate reader with the wavelength correction set at $550 \mathrm{~nm}$. The rated sensitivities of the commercial ELISA kits were $9.3 \mathrm{pg} / \mathrm{ml}$ for IL- 6 and $31.2 \mathrm{pg} / \mathrm{ml}$ for IL-8. Assays were performed in triplicate and repeated three times.

\section{Analysis of NF- $\kappa \mathrm{B}$ p 65 activation and kinase expression}

To identify the mechanism of action of AC-PACs on epithelial cells, their effect on different intracellular proteins associated with inflammation was investigated. Oral epithelial cells prepared as described above were incubated with $50 \mu \mathrm{g} / \mathrm{ml}$ of AC-PACs for $30 \mathrm{~min}$ and then stimulated with $C$. albicans at MOI of 15 for an additional $15 \mathrm{~min}$ at $37^{\circ} \mathrm{C}$ in a $5 \% \mathrm{CO}_{2}$ atmosphere. Epithelial cells stimulated or not with C. albicans in the absence of ACPACs served as controls. Whole-cell extracts were then prepared using nuclear extract kits (Active Motif, Carlsbad, CA) according to the manufacturer's protocol and adjusted to a protein concentration of $1 \mathrm{mg} / \mathrm{ml}$. A sample of cell extracts were shipped frozen to SearchLight Protein Array Service (Pierce Biotechnology, Woburn, MA, USA) for the assay of four phosphorylated protein kinases [AKT (Ser473), AKT (Thr308), MEK1 (Ser217/Ser221), and ERK1/2 (Thr202/Tyr204)] that are involved in inflammatory signalling, by ELISA combined with piezoelectric printing technology. Nuclear factor $-\kappa \mathrm{B}(\mathrm{NF}-\kappa \mathrm{B}) \mathrm{p} 65$, which is involved in secretion of proinflammatory mediators, was determined using a TransAm NF- $\kappa$ B p65 kit (Active Motif) according to the manufacturer's protocol. Assays were performed in triplicate and repeated three times.

\section{Effect of AC-PACs and C. albicans on viability of oral epithelial cells}

Epithelial cells were grown until confluence in DMEM-10\% heat-inactivated FBS medium supplemented with antibiotics at $37^{\circ} \mathrm{C}$ in a $5 \% \mathrm{CO}_{2}$ atmosphere as described above. Epithelial cells were seeded at a concentration of $4 \times 10^{5}$ cells/ml in 96-well microplates and cultured until confluence. Then, cells were treated with increasing concentrations of AC-PACs $(0,6.25,12.5,25,50$ and $100 \mu \mathrm{g} / \mathrm{ml})$, with $C$. albicans at MOIs of 3 and 15, or with both ACPACs and C. albicans. After incubation for $24 \mathrm{~h}$ at $37^{\circ} \mathrm{C}$ in a $5 \% \mathrm{CO}_{2}$ atmosphere, the cell viability was measured. Viability of epithelial cells was determined using a 3-[4, 5dimethylthiazol-2-yl]-2, 5-diphenyltetrazolium (MTT) colorimetric assay (Roche Diagnostics, Mannheim, Germany) according to the manufacturer's protocol. This assay measures mitochondrial dehydrogenase activity. Assays were performed in quadruplicate and repeated three times.

\section{Statistical analysis}

The means \pm standard deviations were calculated. The statistical analysis was performed using Student t-test with a level of significance of $P<0.05$.

\section{Results}

The proanthocyanidin fraction purified from cranberry was characterized by ${ }^{13} \mathrm{C}$ NMR. As shown in Figure 1, the proanthocyanidin molecules consist of epicatechin units with degrees of polymerization (DP) mainly of 4 and 5 containing at least one A-type linkage, as previously reported [18] (Figure 1). In order to investigate the capacity of AC-PACs to alter the virulence properties of C. albicans, we tested their effect on growth, biofilm formation and adhesion to oral epithelial cells and acrylic resin disks. At all tested concentrations, AC-PACs did not affect the growth of C. albicans. However, the biofilm of C. albicans formed after a 48 h-growth was significantly inhibited by AC-PACs in a dose-dependent manner (Figure $2 \mathrm{~A})$. At the lowest concentration tested $(6.25 \mu \mathrm{g} / \mathrm{ml})$, AC-PACs reduced biofilm formation by $23 \% \pm 2.9 \%$, while at $100 \mu \mathrm{g} / \mathrm{ml}$ the inhibition reached $80 \% \pm 4.8 \%$ compared to untreated control (Figure $2 \mathrm{~A}$ ). The phase-contrast images clearly showed a marked reduction of biofilm as well as an alteration in its architecture when C. albicans was grown in the presence of $25 \mu \mathrm{g} / \mathrm{ml}$ of AC-PACs (Figure $2 \mathrm{~B}$ ) as compared to control (Figure 2C). Thereafter, the ability of AC-PACs to cause desorption of a preformed (48 h) biofilm of C. albicans was evaluated. A 30-min treatment of a newly formed biofilm with AC-PACs did not affect significantly their biomass. However, increasing the exposure time of C. albicans biofilms to AC-PACs at $120 \mathrm{~min}$ resulted in a significant detachment. AC-PACs at a concentration ranging from 6.25 to $50 \mu \mathrm{g} / \mathrm{ml}$ were able to reduce preformed biofilms by $25-30 \%$, while the highest concentration $(100 \mu \mathrm{g} / \mathrm{ml})$ caused a $50 \% \pm 8 \%$ desorption of C. albicans biofilm (Figure 3).

The effects of AC-PACs on the adherence properties of C. albicans to oral epithelial cells and acrylic resin discs were then tested. AC-PACs at 25 and $50 \mu \mathrm{g} / \mathrm{ml}$ reduced C. albicans adherence to oral epithelial cells by $42 \% \pm$ $11 \%$ and $90 \% \pm 14 \%$, respectively, while a complete inhibition was observed at $100 \mu \mathrm{g} / \mathrm{ml}$ (Figure 4A). Fluorescence microscopy observations demonstrated a marked reduction in the number of $C$. albicans attached to epithelial cells in the presence of AC-PACs at $50 \mu \mathrm{g} / \mathrm{ml}$ (Figure 4C, E) as compared to untreated control (Figure 4B, D). AC-PACs were also tested for its capacity to inhibit $C$. albicans adhesion to acrylic resin discs, which represent a model for denture materials. The inhibitory effect was dose-dependent, and AC-PACs at the lowest 
<smiles>Oc1cc(O)c2c(c1)O[C@H](c1ccc(O)c(O)c1)[C@H](O)[C@H]2c1c(O)cc(O)c2c1O[C@H](c1ccc(O)c(O)c1)[C@H](O)C2c1c(O)cc(O)c2c1O[C@H](c1ccc(O)c(O)c1)[C@H](O)C2</smiles>

Figure 1 Cranberry proanthocyanidins showing the presence of A-type linkages.

concentration tested $(6.25 \mu \mathrm{g} / \mathrm{ml})$ reduced C. albicans adherence by $32 \%$, while at the highest concentration tested $(100 \mu \mathrm{g} / \mathrm{ml})$ an almost complete inhibition of attachment of $C$. albicans to acrylic resin disks was observed (Figure 5).

To get insight onto the mechanism by which ACPACs reduce C. albicans adhesion, experiments were performed to investigate whether AC-PACs can modify the cell surface hydrophobicity of C. albicans. A 30-min incubation of $C$. albicans with AC-PACs at a concentration of $100 \mu \mathrm{g} / \mathrm{ml}$ decreased the hydrophobicity index (HI) from $54 \% \pm 4 \%$ to $7 \% \pm 2 \%$.

Lastly, we examined the capacity of AC-PACs to modulate the C. albicans-induced inflammatory response in oral epithelial cells. In this purpose, epithelial cells were pre-treated with AC-PACs prior to be stimulated with C. albicans cells at MOI of 3 and 15. In the absence of
AC-PACs, C. albicans significantly and MOI-dependently induced IL-6 and IL-8 secretion by epithelial cells (Figure 6). AC-PACs decreased the secretion of both cytokines in a dose-dependent manner when epithelial cells were infected with C. albicans at either MOI of 3 or 15. More specifically, when epithelial cells were exposed to C. albicans at an MOI of 3, AC-PACs at concentrations of 25,50 , and $100 \mu \mathrm{g} / \mathrm{ml}$ reduced the secretion of IL- 6 by $36 \%, 76 \%$ and $89 \%$, respectively, as compared to control cells not treated with AC-PACs (Figure 6A). In addition, IL-8 secretion was decreased by $48 \%, 94 \%$ and $99 \%$, respectively, as compared to control cells not treated with AC-PACs (Figure 6B). ACPACs also caused a similar inhibition of secretion of both cytokines when $C$. albicans was used at an MOI of 15 (Figure 6). Neither C. albicans nor AC-PACs, alone or in combination, reduced the viability of epithelial 


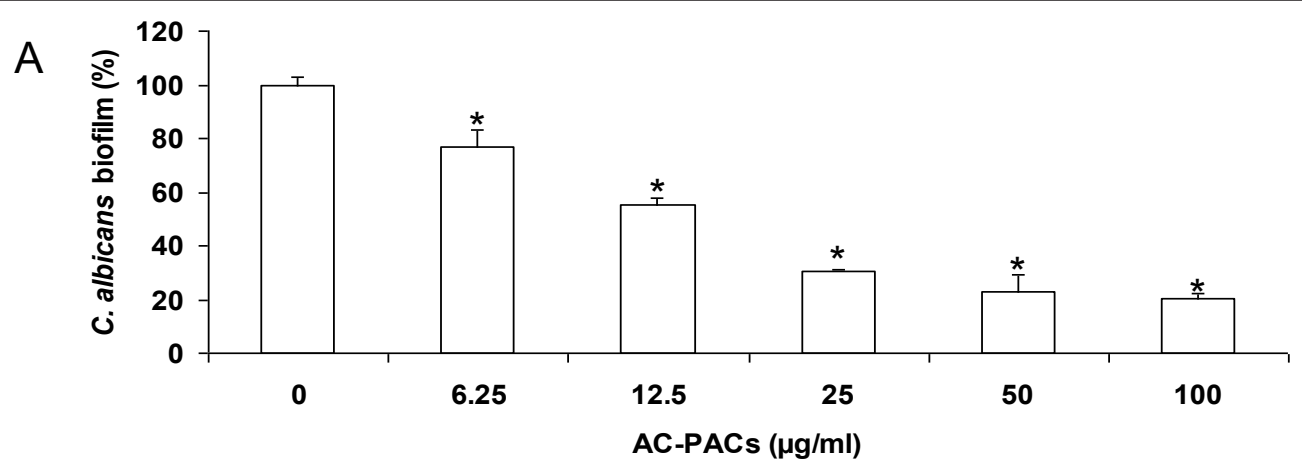

B

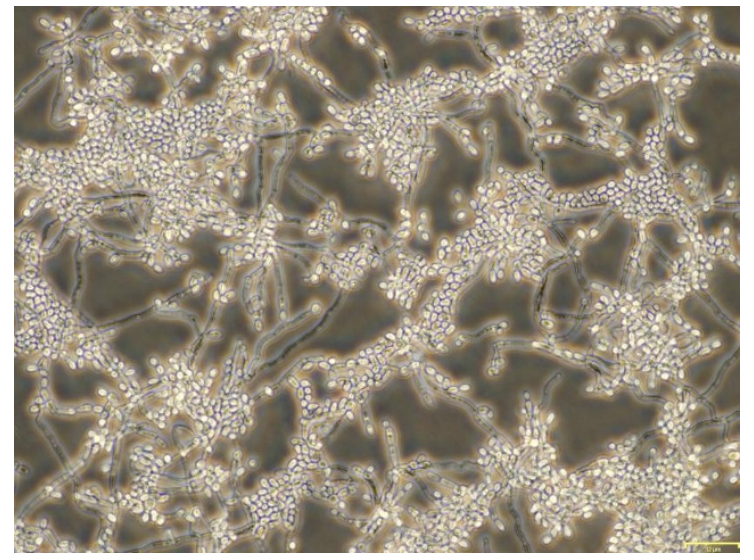

C

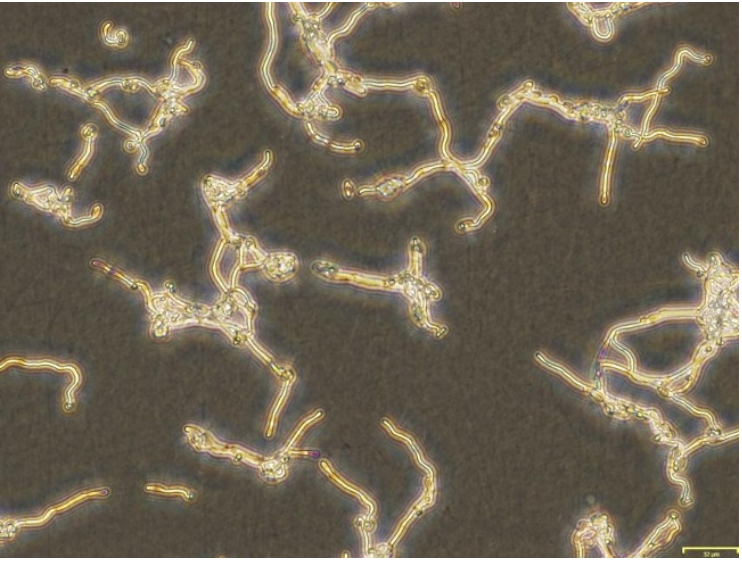

Figure 2 Effect of AC-PACs on C. albicans biofilm formation. Panel A: C. albicans biofilms were quantified by staining with crystal violet. Assays were done in triplicate and the means \pm SD from three independent experiments were calculated. A value of $100 \%$ was assigned to the biofilm formed in the absence of AC-PACs. ${ }^{*}$, significantly lower than the value for the untreated control $(P<0.05)$. Panels B and $C$ : Phase contrast microscopy of biofilms formed in the presence (B) or absence (C) of AC-PACs ( $25 \mu \mathrm{g} / \mathrm{ml})$.

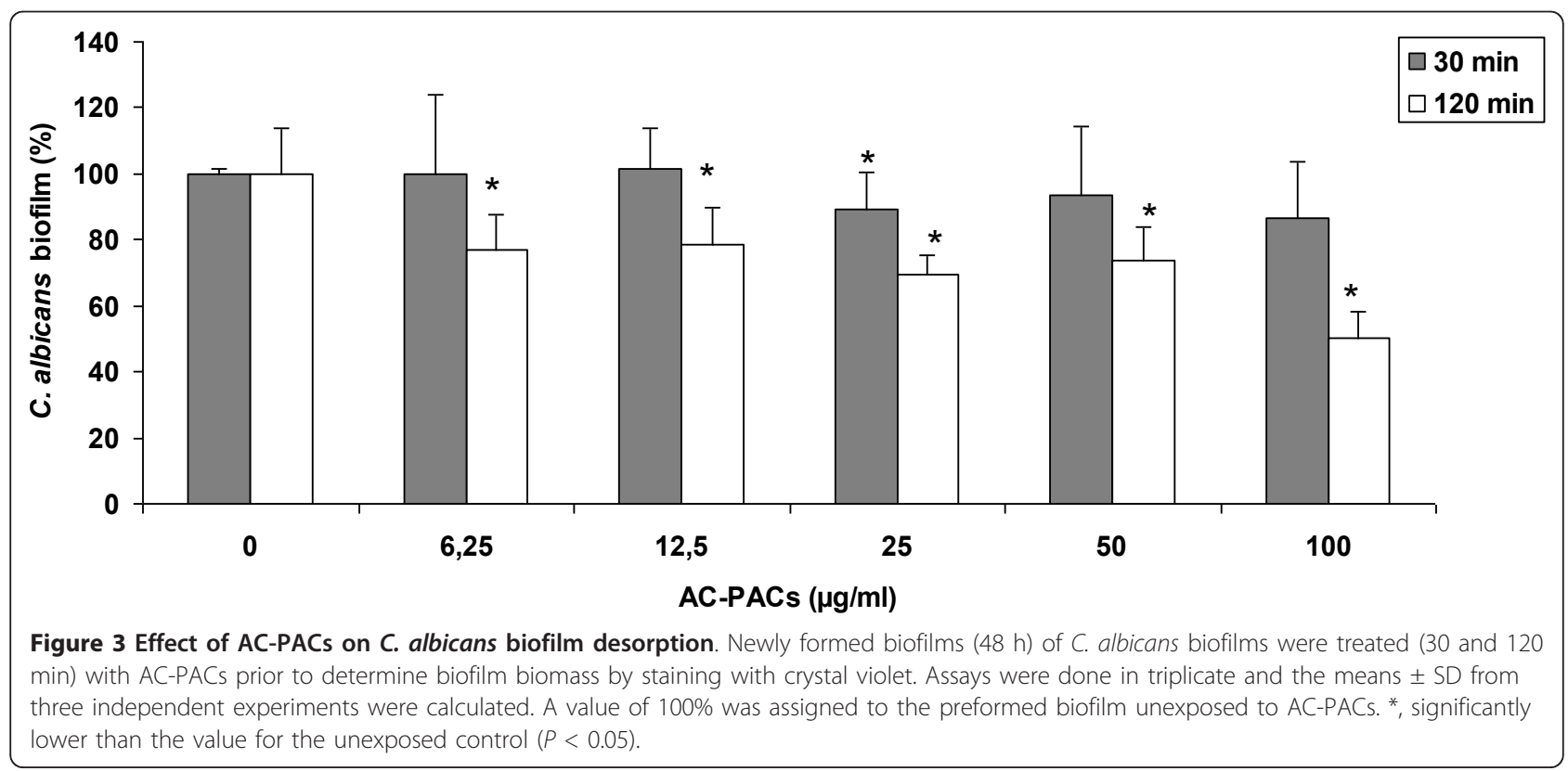




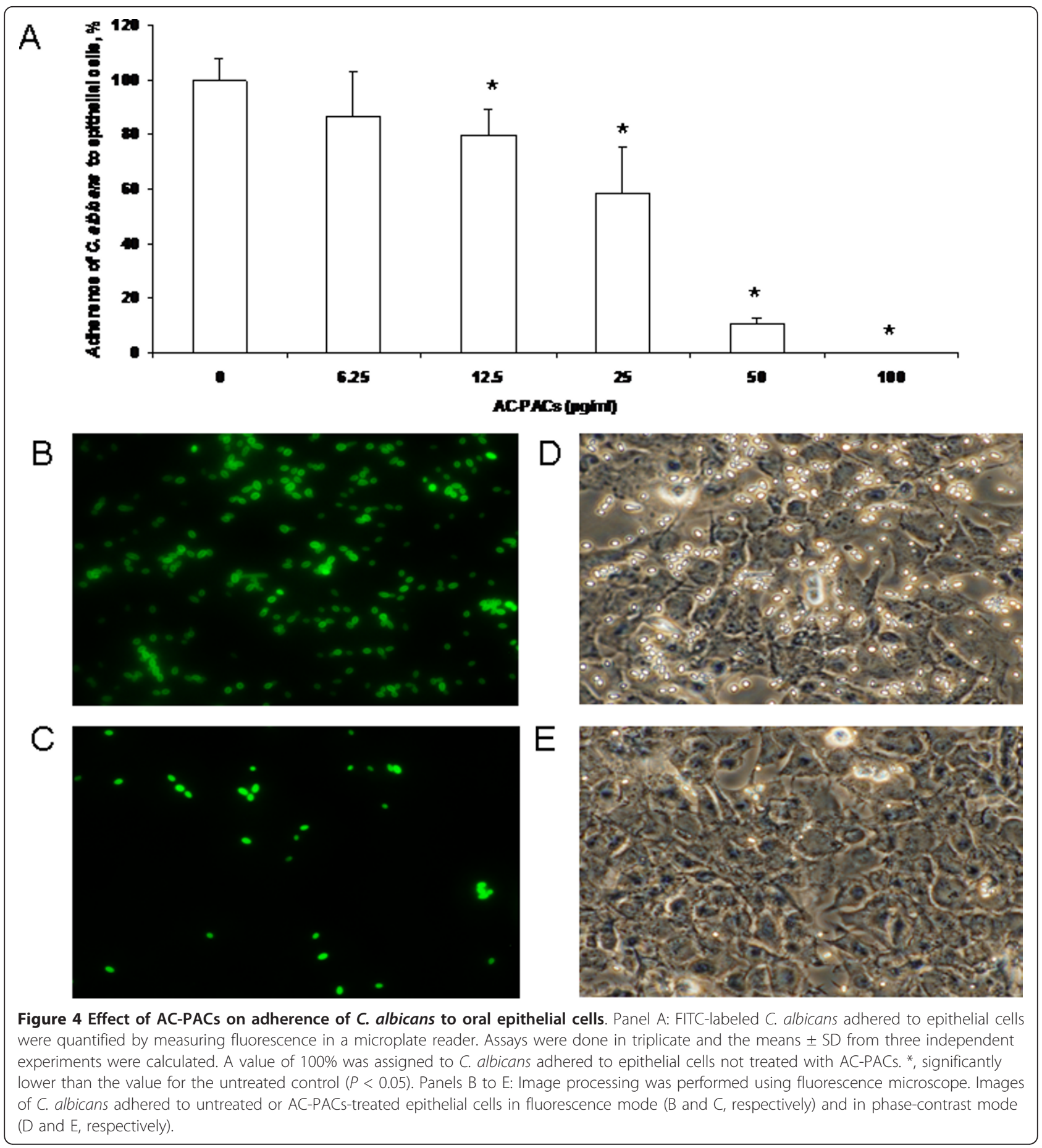

cells as determined with an MTT assay (data not shown).

The relative DNA-binding activity of nuclear transcription factor NF- $\kappa$ B p 65 in epithelial cells infected with $C$. albicans at MOI of 15 was increased up to $290 \% \pm 13 \%$ (Figure 7). Pretreating the cells with AC-PACs at $50 \mu \mathrm{g} /$ $\mathrm{ml}$ prior to stimulating them with $C$. albicans significantly decreased the induced activity of NF- $\kappa \mathrm{B}$ p65, down to the level of non-stimulated GMSM-K cells (Figure 7). Moreover, following a stimulation with C. albicans (MOI of 15), the levels of phosphorylated kinases, AKT (Ser473), AKT (Thr308), MEK1 (Ser217/Ser221) and ERK1/2 (Thr202/Tyr204) were significantly increased by $92 \%, 85 \%, 206 \%$ and $44 \%$, respectively (Table 1). However, when epithelial cells were pretreated with AC-PACs at $50 \mu \mathrm{g} / \mathrm{ml}$, the levels of phosphorylated 


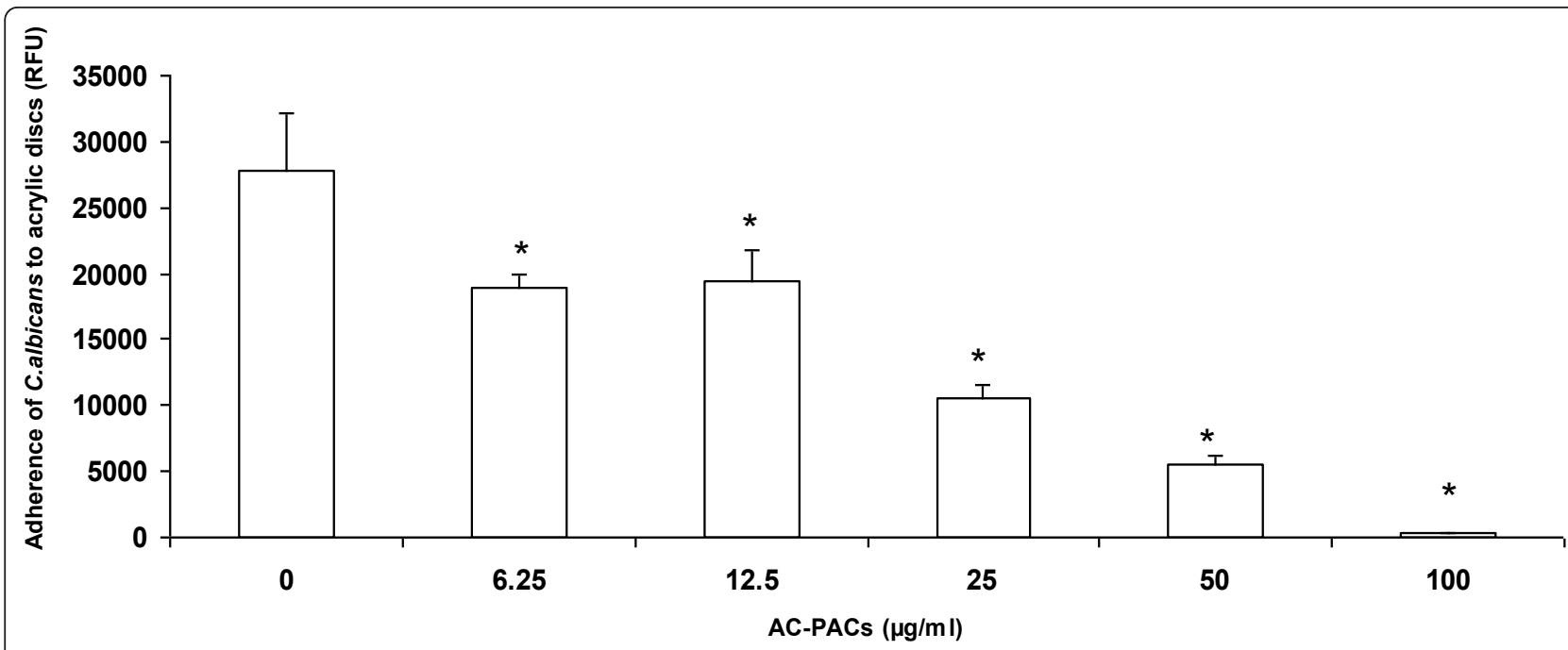

Figure 5 Effect of AC-PACs on adherence of C. albicans to acrylic resin disks. FITC-labeled C. albicans adhered to saliva-coated acrylic resin disks were quantified by measuring fluorescence in a microplate reader. Assays were done in triplicate and the means \pm SD from three independent experiments were calculated. Data were performed as relative fluorescence units (RFU) obtained from the disks incubated with $C$. albicans and AC-PACs, and compared to control disks incubated with C. albicans alone. ${ }^{*}$, significantly lower than the value for the control $(P<$ 0.05).

AKT (Ser473) and MEK1 (Ser217/Ser221) were significantly reduced by $33 \%$ and $43 \%$ respectively, while the elevated phosphorylation of ERK1/2 (Thr202/Tyr204) returned to its basic non-stimulated state. The C. albicans-mediated enhanced phosphorylation level of AKT (Thr308) was not altered by AC-PACs (Table 1).

\section{Discussion}

Oral candidiasis is a common fungal disease for which C. albicans is the major etiological agent. These infections can be controlled by several means, the most effective being a fungicidal approach. However, this approach has numerous draw backs, the most serious one being the emergence and spread of drug resistant strains [25]. A variety of virulence attributes associated to C. albicans are involved in the infection process. For example, the ability to adhere and to form biofilms on biomaterials [26] and oral mucosa [27] allows C. albicans to accumulate in large amounts. In the biofilm, C. albicans is protected from antimicrobial agents and the host immune system. Agents interfering with biofilm formation and adherence properties represent a novel approach to control C. albicans infections. By affecting C. albicans virulence properties, this may minimize the appearance of resistant strains. Previous studies have reported antibiofilm activities of several agents against candidal biofilms [28,29].

Proanthocyanidins isolated from the American cranberry (V. macrocarpon) are composed of oligomers containing at least one A-type interflavan bond, although there are often multiple A-type interflavan linkages at each degree of polymerization within the proanthocyanidin oligomeric series
[20]. Numerous studies have demonstrated antiadhesion and antibiofilm properties of AC-PACs attributed to their unique A-type bond chemical structure [30-34]. While these activities of cranberry PACs have been directed against bacteria including Gram positive [33,35] and Gram negative $[32,34]$, it is still unknown whether cranberry proanthocyanidins are able to exert such properties on eukaryotic fungi. Our study showed that the formation and architecture of C. albicans biofilm were strongly affected by AC-PACs. Moreover, AC-PACs were capable to detach a newly formed biofilm of $C$. albicans, a phenomenon that is likely to alter its biological functions. Importantly, ACPACs exerted their antibiofilm activities while having no effect on fungal growth, which is in agreement with other studies reporting no alteration in bacterial growth and viability due to the presence of AC-PACs [30,34]. The use of such agents that disengage microorganisms from the biofilm without affecting their viability may prove advantageous, as selective pressure and overgrowth of resistant fungus would be avoided [36].

Our study also showed that AC-PACs inhibit C. albicans adherence to oral epithelial cells in a dose-dependent mode. The ability of AC-PACs to inhibit the adherence of C. albicans to epithelial cells suggests that this cranberry fraction may be of interest for the prevention of oral candidiasis. Indeed, adhesion to epithelial cells is a key event in pathogenic lifestyles of C. albicans $[37,38]$ and consequently its prevention could minimize the fungal virulence. C. albicans has been recognized as the primary agent of denture-related stomatitis, an inflammatory process affecting the oral mucosa of $30-60 \%$ of patients 


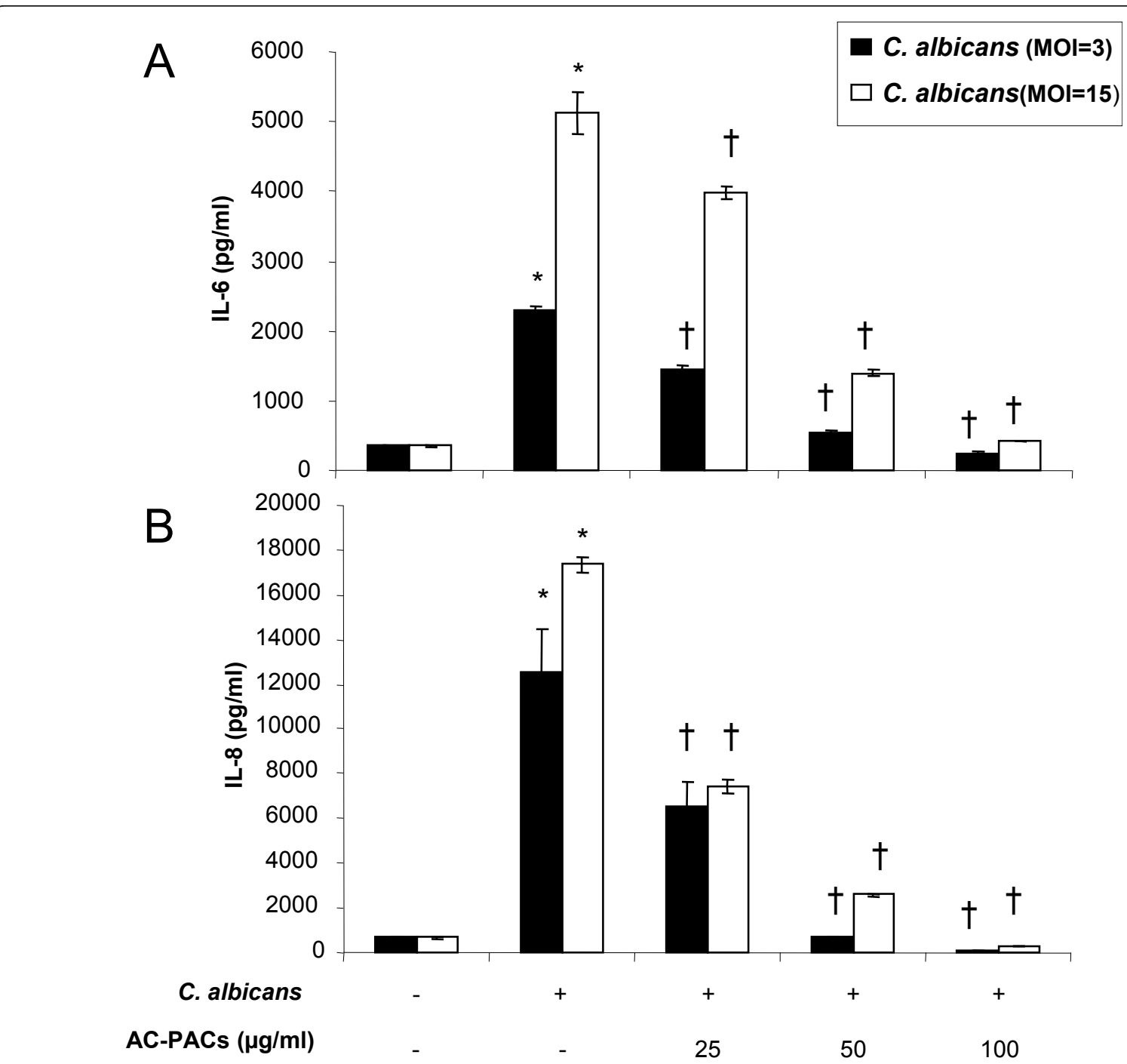

Figure 6 Effect of AC-PACs on IL- 6 and IL-8 secretion by C. albicans (MOI of 3 or 15)-stimulated oral epithelial cells. IL-6 (Panel A) and IL-8 (Panel B) concentrations in the cell-free supernatants were determined by ELISA. Assays were run in triplicate, and the means \pm SD from three independent assays were calculated. *, significantly higher than the value for the unstimulated (C. albicans) control $(P<0.05)$; + , significantly lower than the value for the untreated (AC-PACS) control $(P<0.05)$.

wearing removable dental prostheses $[39,40]$. AC-PACs also significantly reduced $C$. albicans adherence to acrylic resin discs that mimic denture material.

Hydrophobic interactions are generally considered to play an important role in the adherence of $C$. albicans to eukaryotic cells and also to certain inert surfaces, such as prosthetic devices [41]. Therefore, agents able to modify surface characteristics of C. albicans may alter their adherence capacity, and subsequently prevent biofilm formation and subsequently invasion of host cells. In the present study, AC-PACs markedly modified C. albicans cell surface from being highly hydrophobic to hydrophilic. This is in agreement with Ishida et al. [24], who reported that tannins isolated from Stryphnodendron adstringens decrease adherence of C. albicans to mammalian cells and to glass surfaces by lowering the fungi cell surface hydrophobicity [24]. Thus, we propose that the mechanism of antiadhesion and antibiofilm action of AC-PACs may be at least in part attributed to a modification of C. albicans cell surface. Previous reports documented a strong correlation between inhibition of bacterial biofilm formation by various cranberry constituents and reduction of hydrophobicity of bacterial membrane $[42,43]$. Cranberry PACs have been shown to alter specifically and non-specifically bacterial surface macromolecules (fimbriae, LPS) [44]. Interestingly, exposure of bacteria to cranberry juice for even a short time period produced important changes in surface composition [45]. 


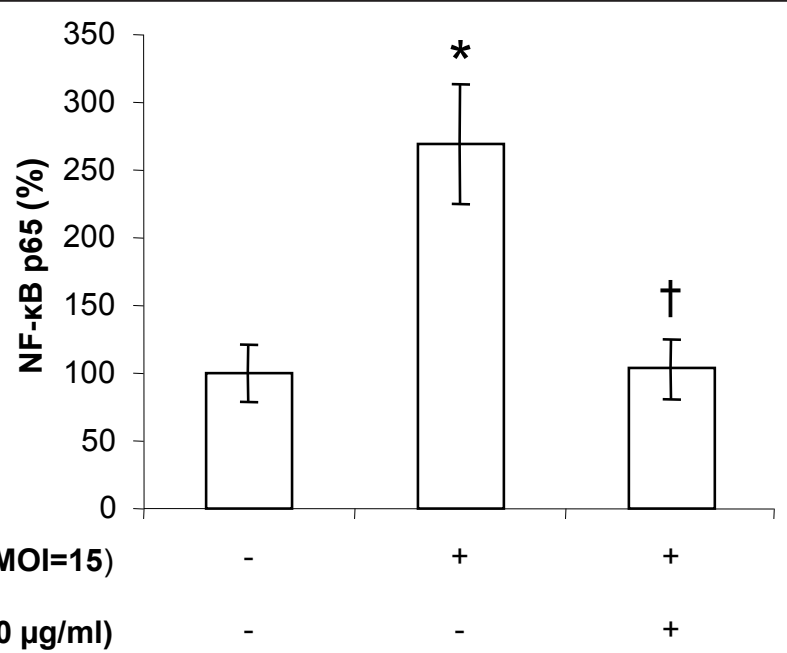

Figure 7 Effect of AC-PACs on NF- $\kappa$ B p65 activation by C. albicans (MOI of 15)-stimulated oral epithelial cells. The activation of NF- $\kappa$ B p65 in the cellular extract was determined by an ELISA-based assay. Assays were run in triplicate, and the means \pm SD from three independent assays were calculated. *, significantly higher than the value for the unstimulated (C. albicans) control $(P<0.05)$; $\dagger$, significantly lower than the value for the untreated (AC-PACS) control $(P<0.05)$.

Therefore, in order to evaluate the exact mode of antiadhesion activity, further experiments are required to determine the effect of AC-PACs on C. albicans cell wallassociated adhesins such as ALS, Hwp1, Eap1, Iff, which mediate fungal adherence $[5,27,46]$.

The tissue homeostasis is regulated by several host factors produced by immune and mucosal cells in a healthy condition. Production of proinflammatory mediators by host cells in response to C. albicans plays a critical role in the activation of immune cells and final clearance of the organism [47]. Infections of oral epithelial cell models with $C$. albicans identified a wide range of pro-inflammatory mediators for which the secretion was markedly increased [48]. In the present study, oral epithelial cells infected with $C$. albicans $(\mathrm{MOI}=15)$ secreted a dramatically increased amount of the proinflammatory cytokines, IL-6 (15-fold) and IL-8 (25fold). IL-6 and IL-8 are considered as the major proinflammatory cytokine and chemokine for the recruitment and activation of neutrophils and macrophages at the site of infection $[49,50]$. However, due to the protecting reaction of the host against fungal pathogens, an accumulation of inflammatory mediators occur and may lead to a chronic and persistent inflammation, and ultimately to tissue destruction mediated by MMPs. In regard to the resolution of the inflammatory process, prevention of excessive activation of innate immunoeffectors or timely inactivation of their function is critical for recovery from fungal infection. We showed a dosedependent inhibitory effect of AC-PACs on C. albicansinduced secretion of IL- 6 and IL- 8 by epithelial cells. These findings are in agreement with previous studies reporting a strong anti-inflammatory activity of proanthocyanidin-rich cranberry fractions towards different human cell lines infected with pathogens [34,51-53].

The mechanisms involved in the proinflammatory mediator overexpression mediated by C. albicans in human keratinocytes includes toll-like receptor-2 (TLR-2)induced activation of intracellular signal transduction pathways including NF- $\kappa \mathrm{B}$ and various kinases [54]. In the present study, we observed a significant activation of NF-

Table 1 Effect of AC-PACs on the levels of phosphorylated protein kinases induced by C. albicans in oral epithelial cells

\begin{tabular}{|c|c|c|c|}
\hline \multirow[t]{3}{*}{ Phosphorylated protein kinase } & \multicolumn{3}{|c|}{ Amounts of phosphorylated protein kinase $(\mathrm{pg} / \mathrm{ml})$} \\
\hline & \multirow[t]{2}{*}{ No stimulation } & \multicolumn{2}{|c|}{ C. albicans stimulation $(\mathrm{MOI}=15)$} \\
\hline & & No pre-treatment & AC-PAC pre-treatment \\
\hline AKT (Ser 473) & $614 \pm 171$ & $1184 \pm 186^{*}$ & $782 \pm 110^{*}$ \\
\hline AKT (Thr 308) & $60 \pm 17$ & $111 \pm 29^{*}$ & $113 \pm 24$ \\
\hline MEK1 (Ser 217/Ser 221) & $2072 \pm 383$ & $6359 \pm 255^{*}$ & $3596 \pm 773^{+}$ \\
\hline ERK1/2 (Thr 202/Tyr 204) & $67 \pm 2$ & $97 \pm 8^{*}$ & $41 \pm 6^{\dagger}$ \\
\hline
\end{tabular}

The data are the means \pm SD of triplicate assays. ${ }^{*}$ significantly higher compared to the unstimulated control $(P<0.05) ;{ }^{\dagger}$ significantly lower compared to the untreated (AC-PACS) control $(P<0.05)$. 
$\kappa \mathrm{B}$ p65 as well as an increased phosphorylation of four kinases, AKT (Ser473), AKT (Thr308), MEK 1(Ser217/ Ser221) and ERK 1/2 (Thr202/Thr204) in oral epithelial cells infected with $C$. albicans. Interestingly, stimulation of cytokine production in human monocytes by proteinases of $C$. albicans was suggested to be regulated via AKT/NF$\kappa \mathrm{B}$ pathway, where AKT initiates translocation of NF- $\kappa \mathrm{B}$ into the nucleus [55]. In addition, it has been shown that inflammatory response of synovial fibroblasts induced by C. albicans involves activation of ERK $1 / 2$ and is associated with NF- $\kappa$ B activation [56]. The enhanced activation of extracellular signal-regulated kinases and suppression of arachidonic acid release in C. albicansinfected macrophages were reduced by MEK1 inhibitor, suggesting that this kinase plays important role in candidiasis-associated inflammatory processes [57]. We provided evidence that AC-PACs inhibited, at least in part, the $C$. albicans-induced secretion of IL- 8 and IL- 6 in oral epithelial cells by their ability to inhibit the activation of $\mathrm{NF}-\kappa \mathrm{B}$ p65. This is in agreement with previous studies showing that cranberry proanthocyanidins exert their antiinflammatory properties by modulating the NF- $\kappa \mathrm{B}$ pathway $[19,34,58]$. Moreover, the present study showed that AC-PACs inhibit the phosphorylation of major intracellular signaling proteins induced by C. albicans. Thus, it is suggested that AC-PACs by interfering in signal transduction cascade may contribute to reduce the impact of host inflammatory processes mediated by elevated production of IL-6 and IL-8 occurring in oral candidiasis.

\section{Conclusion}

The present study demonstrated that AC-PACs, by affecting the virulence properties of $C$. albicans and, parallely, attenuating the inflammation induced by this pathogen, may have a beneficial effect as a novel therapeutic in prevention and treatment of oral candidiasis. Clinical trials are required to demonstrate whether the beneficial properties demonstrated under our assay conditions may be observed in vivo.

\section{Acknowledgements}

This work was supported by a grant from the Cranberry Institute (East Wareham, MA, U.S.A.). We thank V. Murrah (University of North Carolina at Chapel Hill) and J. M. DiRienzo (University of Pennsylvania) for providing the GMSM-K epithelial cell line.

\section{Author details}

'Groupe de Recherche en Écologie Buccale, Faculté de Médecine Dentaire, Université Laval, Quebec City, Quebec, Canada. ${ }^{2}$ Marucci Center for Blueberry and Cranberry Research, Rutgers, The State University of New Jersey, Chatsworth, New Jersey, USA.

\section{Authors' contributions}

All authors contributed equally in data acquisition and in writing of the manuscript. All the authors read and approved the final version of the manuscript.

\section{Competing interests}

The authors declare that they have no competing interests.

Received: 24 October 2011 Accepted: 16 January 2012

Published: 16 January 2012

\section{References}

1. Zunt SL: Oral candidiasis: Diagnosis and treatment. J Pract Hyg 2000, 9:31-36.

2. Ramage G, Tomsett K, Wickes BL, Lopez-Ribot JL, Redding SW: Denture stomatitis: a role for Candida biofilms. Oral Surg Oral Med Oral Pathol Oral Radiol Endod 2004, 98(1):53-59.

3. Wachtler B, Wilson D, Haedicke K, Dalle F, Hube B: From attachment to damage: defined genes of Candida albicans mediate adhesion, invasion and damage during interaction with oral epithelial cells. PLoS One 2011, 6(2):e17046.

4. Li L, Finnegan MB, Ozkan S, Kim Y, Lillehoj PB, Ho CM, Lux R, Mito R, Loewy Z, Shi W: In vitro study of biofilm formation and effectiveness of antimicrobial treatment on various dental material surfaces. Mol Oral Microbiol 2010, 25(6):384-390.

5. Nobile CJ, Nett JE, Andes DR, Mitchell AP: Function of Candida albicans adhesin Hwp1 in biofilm formation. Eukaryot Cell 2006, 5(10):1604-1610.

6. Umeyama T, Kaneko A, Nagai Y, Hanaoka N, Tanabe K, Takano Y, Niimi M, Uehara Y: Candida albicans protein kinase $\mathrm{CaHs} 11 \mathrm{p}$ regulates cell elongation and virulence. Mol Microbiol 2005, 55(2):381-395.

7. Claveau I, Mostefaoui Y, Rouabhia M: Basement membrane protein and matrix metalloproteinase deregulation in engineered human oral mucosa following infection with Candida albicans. Matrix Biol 2004, 23(7):477-486.

8. Dong X, Shi W, Zeng $Q$, Xie L: Roles of adherence and matrix metalloproteinases in growth patterns of fungal pathogens in cornea. Curr Eye Res 2005, 30(8):613-620.

9. Parnanen $\mathrm{P}, \mathrm{Meurman} \mathrm{JH}$, Sorsa T: The effects of Candida proteinases on human proMMP-9, TIMP-1 and TIMP-2. Mycoses 2011, 54(4):325-330.

10. Yuan X, Mitchell BM, Wilhelmus KR: Expression of matrix metalloproteinases during experimental Candida albicans keratitis. Invest ophthalmol Vis Science 2009, 50(2):737-742.

11. Jiang Y, Russell TR, Graves DT, Cheng H, Nong SH, Levitz SM: Monocyte chemoattractant protein 1 and interleukin-8 production in mononuclear cells stimulated by oral microorganisms. Infect Immun 1996, 64(11):4450-4455.

12. Ellepola AN, Samaranayake LP: Oral candidal infections and antimycotics. Crit Rev Oral Biol Med 2000, 11(2):172-198.

13. Chandra J, Mukherjee PK, Leidich SD, Faddoul FF, Hoyer LL, Douglas LJ, Ghannoum MA: Antifungal resistance of candidal biofilms formed on denture acrylic in vitro. J Dent Res 2001, 80(3):903-908.

14. Dorocka-Bobkowska B, Duzgunes N, Konopka K: AmBisome and Amphotericin B inhibit the initial adherence of Candida albicans to human epithelial cell lines, but do not cause yeast detachment. Med Sci Monit 2009, 15(9):BR262-269.

15. Avorn J, Monane M, Gurwitz JH, Glynn RJ, Choodnovskiy I, Lipsitz LA: Reduction of bacteriuria and pyuria after ingestion of cranberry juice. Jama 1994, 271(10):751-754.

16. Neto CC: Cranberry and blueberry: evidence for protective effects against cancer and vascular diseases. Mol Nutr Food Res 2007, 51(6):652-664.

17. Yan X, Murphy BT, Hammond GB, Vinson JA, Neto CC: Antioxidant activities and antitumor screening of extracts from cranberry fruit (Vaccinium macrocarpon). J Agric Food Chem 2002, 50(21):5844-5849.

18. Foo $L Y, L u Y$, Howell $A B$, Vorsa $N$ : The structure of cranberry proanthocyanidins which inhibit adherence of uropathogenic $P$ fimbriated Escherichia coli in vitro. Phytochemistry 2000, 54(2):173-181.

19. La VD, Howell AB, Grenier D: Cranberry proanthocyanidins inhibit MMP production and activity. J Dent Res 2009, 88(7):627-632.

20. Foo LY, Lu Y, Howell AB, Vorsa N: A-Type proanthocyanidin trimers from cranberry that inhibit adherence of uropathogenic P-fimbriated Escherichia coli. J Nat Prod 2000, 63(9):1225-1228.

21. Messier C, Grenier D: Effect of licorice compounds licochalcone A, glabridin and glycyrrhizic acid on growth and virulence properties of Candida albicans. Mycoses 2011, 54(6):e801-6. 
22. Gilchrist EP, Moyer MP, Shillitoe EJ, Clare N, Murrah VA: Establishment of a human polyclonal oral epithelial cell line. Oral Surg Oral Med Oral Pathol Oral Radiol Endod 2000, 90(3):340-347.

23. Avon SL, Goulet JP, Deslauriers N: Removable acrylic resin disk as a sampling system for the study of denture biofilms in vivo. J Prosthet Dent 2007, 97(1):32-38

24. Ishida K, de Mello JC, Cortez DA, Filho BP, Ueda-Nakamura T, Nakamura CV: Influence of tannins from Stryphnodendron adstringens on growth and virulence factors of Candida albicans. J Antimicrob Chemother 2006 , 58(5):942-949

25. White TC, Marr KA, Bowden RA: Clinical, cellular, and molecular factors that contribute to antifungal drug resistance. Clin Microbiol Rev 1998, 11:382-402.

26. Donlan RM: Biofilms and device-associated infections. Emerg Infect Dis 2001, 7(2):277-281

27. Li F, Palecek SP: Distinct domains of the Candida albicans adhesin Eap1p mediate cell-cell and cell-substrate interactions. Microbiology 2008, 154(Pt 4):1193-1203.

28. Martinez LR, Mihu MR, Tar M, Cordero RJ, Han G, Friedman AJ, Friedman JM, Nosanchuk JD: Demonstration of antibiofilm and antifungal efficacy of chitosan against candidal biofilms, using an in vivo central venous catheter model. J Infect Dis 2010, 201(9):1436-1440.

29. Privett BJ, Nutz ST, Schoenfisch MH: Efficacy of surface-generated nitric oxide against Candida albicans adhesion and biofilm formation. Biofouling 2010, 26(8):973-983.

30. Eydelnant IA, Tufenkji N: Cranberry derived proanthocyanidins reduce bacterial adhesion to selected biomaterials. Langmuir 2008, 24(18):10273-10281.

31. Howell AB, Botto H, Combescure C, Blanc-Potard AB, Gausa L, Matsumoto T, Tenke P, Sotto A, Lavigne JP: Dosage effect on uropathogenic Escherichia coli anti-adhesion activity in urine following consumption of cranberry powder standardized for proanthocyanidin content: a multicentric randomized double blind study. BMC Infect Dis 2010, 10:94.

32. Howell AB, Reed JD, Krueger CG, Winterbottom R, Cunningham DG, Leahy M: A-type cranberry proanthocyanidins and uropathogenic bacterial anti-adhesion activity. Phytochemistry 2005, 66(18):2281-2291.

33. Koo H, Duarte S, Murata RM, Scott-Anne K, Gregoire S, Watson GE, Singh AP, Vorsa N: Influence of cranberry proanthocyanidins on formation of biofilms by Streptococcus mutans on saliva-coated apatitic surface and on dental caries development in vivo. Caries Res 2010, 44(2):116-126

34. La VD, Howell AB, Grenier D: Anti-Porphyromonas gingivalis and antiinflammatory activities of A-type cranberry proanthocyanidins. Antimicrob Agents Chemother 54(5):1778-1784.

35. Duarte $S$, Gregoire S, Singh AP, Vorsa N, Schaich $K$, Bowen WH, Koo H: Inhibitory effects of cranberry polyphenols on formation and acidogenicity of Streptococcus mutans biofilms. FEMS Microbiol Lett 2006, 257(1):50-56.

36. Sharon N: Carbohydrates as future anti-adhesion drugs for infectious diseases. Biochim Biophys Acta 2006, 1760(4):527-537.

37. Sundstrom P: Adhesion in Candida spp. Cell Microbiol 2002, 4(8):461-469.

38. Tronchin G, Pihet M, Lopes-Bezerra LM, Bouchara JP: Adherence mechanisms in human pathogenic fungi. Med Mycol 2008, 46(8):749-772

39. Budtz-Jorgensen E: Candida-associated denture stomatitis and angular cheilitis. In Oral candidosis. Edited by: Macfarlane LP, Samaranayake TW. London: Wright-Butterworth and Co. Ltd; 1990:156-183.

40. Radford DR, Sweet SP, Challacombe SJ, Walter JD: Adherence of Candida albicans to denture-base materials with different surface finishes. J Dent 1998, 26(7):577-583.

41. de Souza RD, Mores AU, Cavalca L, Rosa RT, Samaranayake LP, Rosa EA: Cell surface hydrophobicity of Candida albicans isolated from elder patients undergoing denture-related candidosis. Gerodontology 2009, 26(2):157-161

42. Bodet C, Grenier D, Chandad F, Ofek I, Steinberg D, Weiss El: Potential oral health benefits of cranberry. Crit Rev Food Sci Nutr 2008, 48(7):672-680.

43. Yamanaka A, Kimizuka R, Kato T, Okuda K: Inhibitory effects of cranberry juice on attachment of oral streptococci and biofilm formation. Oral Microbiol Immunol 2004, 19(3):150-154.

44. Pinzon-Arango PA, Liu Y, Camesano TA: Role of cranberry on bacterial adhesion forces and implications for Escherichia coli-uroepithelial cell attachment. J Med Food 2009, 12(2):259-270.
45. Liu Y, Black MA, Caron L, Camesano TA: Role of cranberry juice on molecular-scale surface characteristics and adhesion behavior of Escherichia coli. Biotechnol Bioeng 2006, 93(2):297-305.

46. Zhu W, Filler SG: Interactions of Candida albicans with epithelial cells. Cell Microbiol 2010, 12(3):273-282

47. Richardson M, Rautemaa R: How the host fights against Candida infections. Front Biosci (Schol Ed) 2009, 1:246-257.

48. Dongari-Bagtzoglou A, Fidel PL Jr: The host cytokine responses and protective immunity in oropharyngeal candidiasis. J Dent Res 2005, 84(11):966-977.

49. Jones SA: Directing transition from innate to acquired immunity: defining a role for IL-6. J Immunol 2005, 175(6):3463-3468.

50. Rossi D, Zlotnik A: The biology of chemokines and their receptors. Annu Rev Immunol 2000, 18:217-242.

51. Bodet C, Chandad F, Grenier D: Anti-inflammatory activity of a highmolecular-weight cranberry fraction on macrophages stimulated by lipopolysaccharides from periodontopathogens. J Dent Res 2006, 85(3):235-239

52. Bodet C, Chandad F, Grenier D: Cranberry components inhibit interleukin6, interleukin-8, and prostaglandin E production by lipopolysaccharideactivated gingival fibroblasts. Eur J Oral Sci 2007, 115(1):64-70.

53. Huang Y, Nikolic D, Pendland S, Doyle BJ, Locklear TD, Mahady GB: Effects of cranberry extracts and ursolic acid derivatives on P-fimbriated Escherichia coli, COX-2 activity, pro-inflammatory cytokine release and the NF-kappabeta transcriptional response in vitro. Pharm Biol 2009, 47(1):18-25.

54. Li M, Chen Q, Shen Y, Liu W: Candida albicans phospholipomannan triggers inflammatory responses of human keratinocytes through Tolllike receptor 2. Exp Dermatol 2009, 18(7):603-610.

55. Pietrella D, Rachini A, Pandey N, Schild L, Netea M, Bistoni F, Hube B, Vecchiarelli $A$ : The inflammatory response induced by aspartic proteases of Candida albicans is independent of proteolytic activity. Infect Immun 2010, 78(11):4754-4762.

56. Lee HS, Lee CS, Yang CJ, Su SL, Salter DM: Candida albicans induces cyclooxygenase 2 expression and prostaglandin E2 production in synovial fibroblasts through an extracellular-regulated kinase 1/2 dependent pathway. Arthritis Res Ther 2009, 11(2):R48.

57. Parti RP, Loper R, Brown GD, Gordon S, Taylor PR, Bonventre JV, Murphy RC, Williams DL, Leslie CC: Cytosolic phospholipase a2 activation by Candida albicans in alveolar macrophages: role of dectin-1. Am J Respir Cell Mol Biol 2010, 42(4):415-423.

58. Deziel BA, Patel K, Neto C, Gottschall-Pass K, Hurta RA: Proanthocyanidins from the American Cranberry (Vaccinium macrocarpon) inhibit matrix metalloproteinase-2 and matrix metalloproteinase- 9 activity in human prostate cancer cells via alterations in multiple cellular signalling pathways. J Cell Biochem 2010, 111(3):742-754

\section{Pre-publication history}

The pre-publication history for this paper can be accessed here: http://www.biomedcentral.com/1472-6882/12/6/prepub

\section{doi:10.1186/1472-6882-12-6}

Cite this article as: Feldman et al:: Cranberry proanthocyanidins inhibit the adherence properties of Candida albicans and cytokine secretion by oral epithelial cells. BMC Complementary and Alternative Medicine 2012 $12: 6$. 